\title{
Hemoglobin D-Punjab Homozygotes and Double Heterozygotes in Premarital Screening: Case Presentations and Minireview
}

\author{
Srdjan Denic and Abdul-Kader Souid
}

\section{ABSTRACT}

\begin{abstract}
Hemoglobin D-Punjab is the most common variant of hemoglobin D. In premarital screening, molecular testing is often unavailable, and diagnosis (and marriage guidance) often relies on the hemoglobin analysis, family studies and epidemiological facts. The use of latter methods sometimes results in hemoglobin D-Punjab/ß-thalassemia double heterozygote being mistaken for its homozygote, which could be costly. We present the clinical and laboratory characteristics of hemoglobin D-Punjab phenotypes/genotypes in $\mathbf{1 5}$ individuals and review similar reports in the literature. We find that the quantity of hemoglobin D-Punjab in homozygotes is higher than in hemoglobin D-Punjab/ $\beta$-thalassemia double heterozygotes, its fraction $>\mathbf{9 2 \%}$ being consistent with homozygosis. The limitations of this diagnostic criterion are discussed, and clinical severity of this and other hemoglobin D-Punjab double heterozygotes reviewed.
\end{abstract}

Keywords: Hemoglobinopathies; Sickle cell anemia; Thalassemia major; Population genetics; Prevention genetics; Community health services.
Published Online: January 28, 2021

ISSN: $2593-8339$

DOI: $10.24018 /$ ejmed.2021.3.1.681

Srdjan Denic *

Department of Medicine, College of Medicine and Health Sciences, United Arab Emirates University, UAE.

(e-mail: s.denic@uaeu.ac.ae)

Abdul-Kader Souid

Department of Pediatrics, College of Medicine and Health Sciences, United Arab Emirates University, UAE.

*Corresponding Author

\section{INTRODUCTION}

Hemoglobin D ( Hb D) has more than a dozen variants among which $\mathrm{Hb}$ D-Punjab is most common [1], [2]. The variants differ at molecular level, but genetic tests are often unavailable in premarital screening. In practice, the diagnosis and marriage guidance often rely on the results of hemoglobin analysis, family studies and epidemiological knowledge. The use of latter methods has recently resulted in misdiagnosis of $\mathrm{Hb} \mathrm{D}$-Punjab/ $\beta$-thalassemia double heterozygotes [3], [4]. In addition, some uncertainty might exist about other Hb D-Punjab double heterozygotes due to marked geographic variations in frequency of the $\mathrm{Hb} \mathrm{D}$ and other major hemoglobinopathies, small number of reports, evolving methodology of analysis of hemoglobinopathies, and sometimes confusing terminology [1], [5]. In this article, we present $\mathrm{Hb}$ D-Punjab carrier phenotypes, review similar reports in the literature, and categorize the phenotypes/genotypes into three clinical groups:
i) Benign
ii) Afflicted
iii) Uncertain

\section{MATERIALS AND METHODS}

This is a retrospective study of individuals with $\mathrm{Hb} \mathrm{D}$ Punjab from a single hematology clinic in Al Ain, Abu Dhabi, United Arab Emirates (UAE). The study subjects were either referred from the national premarital screening program (Abu Dhabi, UAE) or by members of their family. Laboratory and clinical information were collected from electronic medical records. The complete blood count and hemoglobin analysis were performed using a Cell-DYN Sapphire hematological analyzer (Abbott Diagnostics, Santa Clara, CA, USA) and high-performance liquid chromatography (HPLC; VARIANT II ${ }^{\mathrm{TM}}$, Bio-Rad Laboratories, Hercules, CA, USA), respectively. Hemoglobin-beta locus (HBB; MIM\#141900) analysis was performed by ViennaLab Diagnostics GmbH (Vienna, Austria) and involved the 22 most common deletions within the Indian and Middle Eastern populations. Hemoglobinalpha locus 1 (HBA1; MIM\#141800) and hemoglobin-alpha locus 2 (HBA2; MIM\#141850), which encompass common deletions/duplications, $\mathrm{Hb}$ Constant Spring, and $\alpha$-Saudi alterations, were analyzed by Mayo Clinic Laboratories (Rochester, MN, USA). $H B B$ was not analyzed for the presence of $\mathrm{Hb} \mathrm{D}$.

The diagnosis of $\mathrm{Hb}$ D-Punjab (HBB: c.364G>C, p.Glu122Gln) was deduced from the results of HPLC hemoglobin analysis, taking the following aspects into consideration:

i) All subjects were members of the same (Balushi) kinship, and tribal allegiance was determined from the family name.

ii) The group migrated to the Arabian Peninsula (UAE and Oman) from Baluchistan (Pakistan and Iran) two 
centuries ago, i.e., originates from areas close to the Indian regions of Punjab and Gujarat, which have the highest recorded frequency of $\mathrm{Hb} \mathrm{D}$ carriers $(1.5 \%-3 \%)$ [2], [6], [7].

iii) They practice intra-family (close cousin or consanguineous) and intra-tribal (endogamous) marriages, which limit gene flow. The literature was queried using the PubMed, Google Scholar, and ResearchGate databases using multiple $\mathrm{Hb}$ D-related search terms and by crossreferencing the articles.

\section{RESULTS}

\section{A. Case Presentations}

The results of 13 subjects with $\mathrm{Hb}$ D-Punjab and 2 with $\beta$-thalassemia are shown in Tables $1-3$. All subjects were asymptomatic and had normal findings on physical examination.
TABLE 1: LABORATORY RESUlTS OF Two PROSPECTIVE COUPLES WITH HB D-PUNJAB

\begin{tabular}{|c|c|c|c|c|}
\hline \multicolumn{2}{|c|}{ Couple A } & \multirow{2}{*}{ Sex-age } & \multicolumn{2}{|c|}{ Couple B } \\
\hline$F-36$ & $M-27$ & & $F-36$ & $M-35$ \\
\hline 4.9 & 7.2 & $\mathrm{RBC}\left(\times 10^{12} / \mathrm{L}\right)$ & 5.3 & 5.6 \\
\hline - & - & $\begin{array}{l}\text { Reticulocytes } \\
\left(\times 10^{9} / \mathrm{L}\right)\end{array}$ & 61.8 & - \\
\hline 110 & 140 & $\begin{array}{l}\text { Hemoglobin } \\
(\mathrm{g} / \mathrm{L})\end{array}$ & 114 & 130 \\
\hline 69.1 & 58.2 & MCV (fL) & $63.3^{\mathrm{a}}$ & 73.2 \\
\hline 16.0 & 16.9 & RDW (\%) & 21.6 & 17.2 \\
\hline 12 & 146 & Ferritin $(\mu \mathrm{g} / \mathrm{L})$ & 38 & - \\
\hline 61.8 & 3.6 & $\mathrm{Hb} \mathrm{A}(\%)$ & 0 & 94.3 \\
\hline 2.8 & 5.8 & $\mathrm{Hb}$ A2 (\%) & $3.8^{\mathrm{a}}$ & 4.5 \\
\hline 0 & 0.8 & $\mathrm{Hb} \mathrm{F} \mathrm{( \% )}$ & 0.7 & 1.2 \\
\hline 35.4 & 89.8 & $\mathrm{Hb} \mathrm{D}(\%)$ & 95.5 & 0 \\
\hline & c. $92+5 \mathrm{G}>\mathrm{C}$ & $H B B$ analysis & Negative & c. $92+5 \mathrm{G}>\mathrm{C}$ \\
\hline$\alpha_{1} \alpha_{2} /-^{3.7} \alpha_{2}$ & $\alpha_{1} \alpha_{2} /-^{3.7} \alpha_{2}$ & $\begin{array}{c}H B A 1 / H B A 2 \\
\text { analysis }\end{array}$ & Negative & $-{ }^{3.7} \alpha_{2} /-{ }^{3.7} \alpha_{2}$ \\
\hline $\begin{array}{l}\text { Hb D trait } \\
\text { Silent } \alpha- \\
\text { Thal trait }\end{array}$ & $\begin{array}{c}\mathrm{Hb} \mathrm{D} / \beta^{+} \\
\text {Silent } \\
\alpha-\text { Thal trait }\end{array}$ & Phenotype & $\mathrm{Hb} \mathrm{D} / \mathrm{D}$ & $\begin{array}{l}\beta^{+}-\text {Thal trait } \\
\alpha-\text { Thal trait }\end{array}$ \\
\hline
\end{tabular}

TABLE 2: LABORATORY RESULTS OF TwO FAMILIES WITH HB D-PUNJAB

\begin{tabular}{|c|c|c|c|c|c|c|c|c|c|c|}
\hline \multicolumn{5}{|c|}{ Family 1} & & \multicolumn{5}{|c|}{ Family 2} \\
\hline Mother & Father & Daughter-7 & Daughter-17 & Daughter-19 & & Mother & Father & Son- $6^{a}$ & Son-7 & Daughter-9 \\
\hline 5.8 & & 6.3 & 5.8 & 5.7 & $\mathrm{RBC}\left(* 10^{12} / \mathrm{L}\right)$ & 5.2 & 5.99 & 6.3 & 4.8 & 4.9 \\
\hline- & & 33.8 & 80.0 & 86.1 & $\begin{array}{l}\text { Reticulocytes } \\
\left(\times 10^{9} / \mathrm{L}\right)\end{array}$ & 42.3 & 57.8 & 59.6 & 59.9 & 16.7 \\
\hline 114 & & 125 & 121 & 114 & Hemoglobin $(\mathrm{g} / \mathrm{L})$ & 130 & 133 & 117 & 117 & 122 \\
\hline 57.1 & & 58.3 & 64.0 & 58.0 & MCV (fL) & 77.8 & 72.6 & 56.2 & 73.4 & 76.1 \\
\hline 16.3 & & 13.8 & 14.1 & 13.9 & RDW (\%) & 13.2 & 14.1 & 16.6 & 12.4 & 13.3 \\
\hline 63.5 & & 69 & & 29 & Ferritin $(\mu \mathrm{g} / \mathrm{L})$ & & & 40 & & \\
\hline $0 / 0$ & & 0 & 0 & 0 & $\mathrm{Hb} \mathrm{A}(\%)$ & 61.8 & 94.3 & 3.5 & 60.6 & 57.5 \\
\hline $3.8 / 3.7$ & & $2.5^{\mathrm{a}}$ & 2.8 & 3.0 & $\mathrm{Hb}$ A2 (\%) & 3.0 & 5.2 & 6.3 & 3.1 & 3.1 \\
\hline $0.4 / 0.4$ & & 2.2 & 0.5 & 0.6 & $\mathrm{Hb} \mathrm{F}(\%)$ & 0 & 0.5 & 1.7 & 0.5 & 0.4 \\
\hline $95.8 / 95.8$ & & 95.3 & 96.7 & 96.4 & $\mathrm{Hb} \mathrm{D}(\%)$ & 35.2 & 0 & 88.5 & 35.8 & 39.0 \\
\hline $\begin{array}{c}\mathrm{Hb} \mathrm{D} / \mathrm{D} \\
\alpha-\text { Thal trait }\end{array}$ & Unknown & $\begin{array}{c}\mathrm{Hb} \mathrm{D} / \mathrm{D} \\
\alpha-T h a l \text { trait }\end{array}$ & $\begin{array}{c}\mathrm{Hb} \mathrm{D} / \mathrm{D} \\
\alpha \text {-Thal trait }\end{array}$ & $\begin{array}{c}\mathrm{Hb} \mathrm{D} / \mathrm{D} \\
\alpha-T h a l \text { trait }\end{array}$ & Phenotype & $\begin{array}{c}\mathrm{Hb} \mathrm{D} \\
\text { trait }\end{array}$ & $\begin{array}{c}\beta \text {-Thal } \\
\text { trait }\end{array}$ & $\begin{array}{c}\mathrm{Hb} \\
\mathrm{D} / \beta^{+}\end{array}$ & $\begin{array}{c}\mathrm{Hb} \mathrm{D} \\
\text { trait }\end{array}$ & $\begin{array}{c}\mathrm{Hb} \mathrm{D} \\
\text { trait }\end{array}$ \\
\hline
\end{tabular}

TABLE 3: LABORATORY RESULTS OF TWO BIOLOGICALLY UNRELATED CHILDREN WITH HB D-PUNJAB

\begin{tabular}{ccc}
\hline$F-7$ & Sex-age & $M-4$ \\
\hline 6.6 & RBC $\left(\times 10^{12} / \mathrm{L}\right)$ & 5.62 \\
109 & Reticulocytes $\left(\times 10^{9} / \mathrm{L}\right)$ & - \\
121 & Hemoglobin $(\mathrm{g} / \mathrm{L})$ & 107 \\
62.0 & MCV $(\mathrm{fL})$ & 61.4 \\
13.1 & RDW $(\%)$ & 14.6 \\
- & Ferritin $(\mu \mathrm{g} / \mathrm{L})$ & 32.8 \\
0 & Hb A $(\%)$ & 68.3 \\
2.6 & Hb A2 $(\%)$ & 2.3 \\
4.8 & Hb F $(\%)$ & 0.4 \\
92.6 & Hb D $(\%)$ & 29.0 \\
5.6 & Hb Bart $(\%)$ & 9.7 \\
Hb DD & Phenotype & Hb D trait \\
$\alpha-$ Thal trait & & $\alpha-$ Thal trait \\
\hline
\end{tabular}

\section{DISCUSSION}

All subjects with Hb D-Punjab - heterozygotes $(n=5)$, homozygotes $(\mathrm{n}=6)$, and $\mathrm{Hb} \mathrm{D}$-Punjab/ $\beta$-thalassemia double heterozygotes $(n=2)$ - were members of the same Balushi kinship group.

\section{A. Hb D-Punjab Heterozygote}

In five subjects with $\mathrm{Hb} \mathrm{D}$ trait (Tables 1-3), the total hemoglobin level was normal or slightly decreased, MCV was decreased, and the fraction of $\mathrm{Hb} \mathrm{D}$ was between $29 \%$ and $39 \%$. This is similar to results of other studies and low $\mathrm{MCV}$ is often related to coinheritance of $\alpha$-thalassemia [8][11]; in population without $\alpha$-thalassemia $\mathrm{Hb}$ D-Punjab heterozygotes have normal hemoglobin levels and MCV [12]. In short, the Hb D-Punjab trait is clinically silent [8],

\section{[13].}

\section{B. Hb D-Punjab Homozygote}

Five of the six of our subjects with $\mathrm{Hb}$ D-Punjab homozygosis have normal hemoglobin comprising of high $\mathrm{Hb} \mathrm{D}$, absent $\mathrm{Hb} \mathrm{A}$, and normal $\mathrm{Hb} \mathrm{A} 2$ fraction (Tables 13). In all six subjects, however, Hb D-Punjab fraction was $>92 \%$. This high fraction was reported by others in Hb DPunjab homozygotes (Table 4). As mentioned above, low $\mathrm{MCV}$ is likely a result of coinherited $\alpha$-thalassemia, which is common in our and other studied populations [14]-[16]. We excluded the results of one report due to issues with selection of study subjects [17]. Only one of our six subjects had possible hemolysis solely based on a borderline high reticulocyte count (Table 3, F-7). Similar mild hemolysis was previously reported in one subject [18]. In contrast, two studies that evaluated blood donated by two Hb D-Punjab homozygotes showed that it could be used for transfusion purposes [15], [19].

This benign clinical phenotype of $\mathrm{Hb}$ D-Punjab heterozygote and homozygote explains the gene's wide distribution and relatively high frequency in many human groups [1], [2]. The HBB:c.364G>C, p.Glu122Gln variant has independently originated in the Mediterranean region and Asia approximately 40,000 years ago [20]. This occurred much earlier than the emergence of endemic malaria (approximately 10,000 years ago) and malarialinked hemoglobinopathies [21]. Thus, Hb D-Punjab could either be a neutral mutation at drift or an adaptation to unknown environmental challenge. 
TABLE 4: FRACTIONS OF HB D-PunJaB IN HB D-PunjaB HOMOZYGOTES AND HB D-PUNJAB/B-THALASSEMIA DOUBLE HETEROZYGOTES

\begin{tabular}{|c|c|c|c|c|c|}
\hline $\mathrm{N}$ & $\mathrm{Hb} \mathrm{D} / \mathrm{D}$ & $\mathrm{Hb} \mathrm{D} / \beta$ & $\mathrm{N}$ & Method & Reference \\
\hline \multirow[t]{3}{*}{6} & $92.6 \%-96.7 \%$ & $88.5 \%, 89.8 \%$ & 2 & HPLC & This study \\
\hline & & $81.9 \%$ & 1 & $\mathrm{CE}$ & [24] \\
\hline & & $89.2 \%$ & 1 & HPLC & [3] \\
\hline \multirow{5}{*}{$\begin{array}{l}3 \\
1\end{array}$} & $96.9 \%-97.0 \%$ & $90.9 \%, 91.8 \%$ & 2 & HPLC & [25] \\
\hline & $96.2 \%$ & & & Unknown & [22] \\
\hline & & $\begin{array}{c}82.0 \%, 83.9 \% \\
85.3 \%\end{array}$ & 3 & HPLC & [4] \\
\hline & & $79.0 \%$ & 1 & HPLC & [26] \\
\hline & & $85.7 \%, 86.3 \%$ & 2 & HE, LPLC & [26] \\
\hline \multirow[t]{3}{*}{1} & $96.6 \%$ & & & $\mathrm{HE}$ & [17] \\
\hline & & $88.0 \%$ & 1 & HPLC & [6] \\
\hline & & $\begin{array}{c}94.2 \%, 91.0 \%, \\
94.5 \% *\end{array}$ & 3 & $\mathrm{HE}$ & [23] \\
\hline
\end{tabular}

HPLC, high-pressure liquid chromatography; LPLC, low-pressure liquid chromatography; CE, capillary electrophoresis; HE, hemoglobin (cellulose acetate) electrophoresis.

* In all three subjects, the $\mathrm{Hb} \mathrm{A} 2$ fraction was elevated and $\mathrm{Hb} \mathrm{A}$ was absent.

\section{Hb D-Punjab/ $\beta$-thalassemia Double Heterozygotes}

In our study, two individuals with the $\mathrm{Hb}$ D-Punjab/ $\beta$ genotype had normal total hemoglobin levels, comprising high $\mathrm{Hb} \mathrm{D}$ fraction (89\% and $90 \%$ ), low $\mathrm{Hb}$ A fraction (3.5\% and 3.6\%), and elevated $\mathrm{Hb} \mathrm{A} 2$ fraction $(6.3 \%$ and $5.8 \%$ ); both subjects had low MCV (Tables 1 and 2). Other studies have reported similar findings in $\mathrm{Hb} \mathrm{D}$-Punjab/ $\beta$ thalassemia double heterozygotes [3], [4], [6], [16], [22][26]. Overall, we find that 14 of 16 subjects with this genotype/phenotype have Hb D fraction < $92 \%$ (Table 4).

The $\mathrm{Hb}$ D-Punjab homozygote and its $\beta$-thalassemia double heterozygotes are often confused. In one report, reliance on low $\mathrm{MCV}$ for the diagnosis of $\mathrm{Hb} \mathrm{D} / \beta$ thalassemia heterozygosis has resulted in misdiagnosis of $\mathrm{Hb}$ D-Punjab homozygote [27]. In general, low MCV is of little value for diagnosis of $\mathrm{Hb} \mathrm{D}$-Punjab/ $\beta$ double heterozygote because of a high prevalence of the $\alpha$ thalassemia in many populations. In other reports, $\mathrm{Hb}$ DPunjab/ $\beta$-thalassemia double heterozygotes were misdiagnosed as homozygotes because of normal $\mathrm{Hb}$ A2 level [3], [4]. In general, the $\mathrm{Hb} \mathrm{A} 2$ level is affected by coinherited $\alpha$-thalassemia, iron deficiency, $\beta$-globin gene haplotype, and environmental factors [28], [29]. A review of at least one report suggests that administrative and technical inaccuracies should also be considered [3]. In this context, our finding of an $\mathrm{Hb} \mathrm{D}$ fraction of $>92 \%$ in $\mathrm{Hb}$ D-Punjab homozygotes could be useful in performing accurate diagnosis if molecular study is unavailable. This finding requires further study as two individuals with $\mathrm{Hb} \mathrm{D}$ Punjab/ $\beta^{\circ}$-thalassemia had $\mathrm{Hb}$ D-Punjab fractions of $94 \%$ (Table 4) and were shown to be exceptions to this rule; however, they were the only subjects in whom hemoglobin was analyzed using hemoglobin gel electrophoresis [22].

In one subject (F-36; Table 1, Couple B), $H H B$ analysis for $\mathrm{Hb}$ D-Punjab was needed but was unavailable. She had a high $\mathrm{Hb} \mathrm{D}$ fraction (95.5\%), absence of $\mathrm{Hb} \mathrm{A}$, slightly elevated $\mathrm{Hb} \mathrm{A} 2$ fraction $(3.6 \%, 3.7 \%$, and $3.8 \%$ on repeated examinations), and low MCV. She intends to marry a noncousin with the $\beta$-thalassemia trait from the same tribe and it is essential that the $\mathrm{Hb} \mathrm{D}$-Punjab/ $\beta$-thalassemia genotype is excluded in her. The study of hemoglobin in this subject's parents could not be performed and the analyses of $H B B$ and
$H B A 1$ as well as $H B A 2$ did not result in detection of $\alpha$ - and $\beta$-thalassemia deletions/mutations. However, low MCV is consistent with the presence of the thalassemia trait. We think our results are most likely due to a limited spectrum of variants of $H B B$ and $H B A$ covered by our investigation and a high diversity of thalassemia alleles in our population [11], [30], [31]. In this context, Hb D fraction of $>92 \%$ in our subject supports the diagnosis of $\mathrm{Hb}$ D-Punjab homozygosis.

\section{Hb D-Punjab/S Double Heterozygote}

The patients with $\mathrm{Hb}$ D-Punjab/S genotype/phenotype have diversity of clinical presentations, ranging from asymptomatic to severe anemia [32]-[40]. Their prognosis is better than that of patients with $\mathrm{Hb} \mathrm{S/S}$, and the unpredictability of presentation is affected by the $\mathrm{Hb} \mathrm{F}$ level, $\alpha$-thalassemia, $H B B$ haplotype, age, and environmental factors [37], [41].

\section{E. Hb D-Punjab/E Double Heterozygote}

The benign phenotype of $\mathrm{Hb}$ D-Punjab/E double heterozygotes has been reported in at least six healthy individuals [42]-[44]. They had either a normal or a slightly decreased hemoglobin with $\mathrm{Hb} \mathrm{D}$ fraction always higher than that of $\mathrm{Hb} \mathrm{E}$.

\section{F. Hb D-Punjab/C Double Heterozygote}

The only report of $\mathrm{Hb} \mathrm{D}-\mathrm{Punjab} / \mathrm{C}$ double heterozygotes, published in 2020, describes a young adult with an initial misdiagnosis of mild sickle cell disease [45]. As only one case has been reported to date, the generalization regarding its clinical phenotype is limited.

\section{G. Hb D-Punjab Carriers as Prospective Parents}

In addition to the six most common $\mathrm{Hb}$ D-Punjab phenotypes/genotypes reviewed above, $\mathrm{Hb}$ D-Punjab carriers could produce offspring with many other genotypes (Table 5). In premarital counseling, each possible genotype must be considered for each couple. The fetal risk of a clinically significant hemoglobinopathy has been graded in a proposed guide (Table 5):

i) Green indicates absence of such a risk in the $\mathrm{Hb} \mathrm{D}$ Punjab carrier genotypes/phenotypes, as discussed above.

ii) Yellow indicates a gray zone in decision-making owing to insufficient knowledge.

iii) Red indicates high fetal risk due to one or more possibly deleterious genotypes/phenotypes in offspring.

\section{CONCLUSION}

All $\mathrm{Hb}$ D-Punjab double heterozygotes are clinically benign except $\mathrm{Hb} \mathrm{D}-\mathrm{Punjab} / \mathrm{S}$. Fraction of $\mathrm{Hb} \mathrm{D}$ in $\mathrm{Hb} \mathrm{D}-$ Punjab homozygotes is higher than in $\mathrm{Hb} \mathrm{D}$-Punjab/ $\beta$ double heterozygotes and value of $92 \%$ could be used as the diagnostic cutoff. 


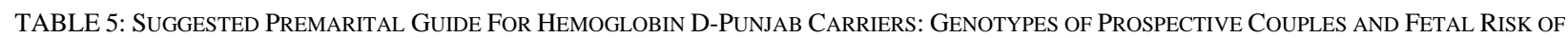
CLINICALLY SIGNIFICANT HEMOGLOBINOPATHY ${ }^{\mathrm{a}}$

\begin{tabular}{|c|c|c|c|c|c|c|c|c|c|c|c|c|c|c|c|}
\hline & \multirow[b]{2}{*}{ Genotypes } & \multirow[b]{2}{*}{$\mathrm{A} / \mathrm{A}$} & \multicolumn{13}{|c|}{ Spouse B } \\
\hline & & & $\mathrm{A} / \beta$ & $\mathrm{A} / \mathrm{S}$ & $\mathrm{D} / \mathrm{A}$ & $\mathrm{D} / \mathrm{D}$ & $\mathrm{D} / \beta$ & $\mathrm{D} / \mathrm{S}$ & $\mathrm{D} / \mathrm{E}$ & $\mathrm{D} / \mathrm{C}$ & $\mathrm{A} / \mathrm{E}$ & $\mathrm{E} / \mathrm{E}$ & $\mathrm{A} / \mathrm{C}$ & $\mathrm{C} / \mathrm{C}$ & $\beta / \beta^{\mathrm{b}}$ \\
\hline \multirow{6}{*}{$\begin{array}{l}\varangle \\
0 \\
\mathscr{0} \\
\tilde{0} \\
\text { के }\end{array}$} & $\mathrm{D} / \mathrm{A}$ & & & & & & & $\mathrm{D} / \mathrm{S}$ & & $\mathrm{D} / \mathrm{C}$ & & & $\mathrm{D} / \mathrm{C}$ & $\mathrm{D} / \mathrm{C}$ & \\
\hline & $\mathrm{D} / \mathrm{D}$ & & & & & & & $\mathrm{D} / \mathrm{S}$ & & & & & $\mathrm{D} / \mathrm{C}$ & $\mathrm{D} / \mathrm{C}$ & \\
\hline & $D / \beta$ & & $\beta / \beta$ & $S / \beta$ & & & $\beta / \beta$ & $S / \beta$ & $E / \beta$ & $\mathrm{C} / \beta$ & $\mathrm{E} / \beta$ & $E / \beta$ & $\mathrm{C} / \beta$ & $\mathrm{C} / \beta$ & $\beta / \beta$ \\
\hline & $\mathrm{D} / \mathrm{S}$ & & $S / \beta$ & $\mathrm{S} / \mathrm{S}$ & $\mathrm{D} / \mathrm{S}$ & $\mathrm{D} / \mathrm{S}$ & $S / \beta$ & $\mathrm{S} / \mathrm{S}^{\mathrm{c}}$ & $\mathrm{D} / \mathrm{S}^{\mathrm{c}}$ & $\mathrm{S} / \mathrm{C}$ & $\mathrm{E} / \mathrm{S}$ & $\mathrm{E} / \mathrm{S}$ & $\mathrm{S} / \mathrm{C}$ & $\mathrm{S} / \mathrm{C}$ & $\mathrm{S} / \beta$ \\
\hline & $\mathrm{D} / \mathrm{E}$ & & & & & & $E / \beta$ & $\mathrm{D} / \mathrm{S}^{\mathrm{c}}$ & & $\mathrm{C} / \mathrm{E}$ & & & $\mathrm{C} / \mathrm{E}$ & $\mathrm{C} / \mathrm{E}$ & $E / \beta$ \\
\hline & $\mathrm{D} / \mathrm{C}$ & & & & & $\mathrm{D} / \mathrm{C}$ & $C / \beta$ & $\mathrm{D} / \mathrm{S}^{\mathrm{c}}$ & $\mathrm{C} / \mathrm{E}$ & & $\mathrm{C} / \mathrm{E}$ & $\mathrm{C} / \mathrm{E}$ & & $\mathrm{D} / \mathrm{C}$ & $\mathrm{C} / \beta$ \\
\hline
\end{tabular}

${ }^{\text {a }}$ Some genotypes have marked phenotype heterogeneity.

${ }^{\mathrm{b}}$ Thalassemia intermedia.

${ }^{\mathrm{c}}$ More than one possible genotype resulting in a clinically significant disease.

Legend

\begin{tabular}{|c|c|}
\hline Alert & Odds of clinically significant hemoglobin disease in offspring \\
\hline & $>0$ \\
\hline & $\rightarrow 0$ \\
\hline & $\begin{array}{c}\text { Unknown, small sample, limited information, or high phenotype } \\
\text { heterogeneity }\end{array}$ \\
\hline $\mathrm{C} / \mathrm{E}$ & $>0$ for shown genotype \\
\hline
\end{tabular}

\begin{tabular}{|c|c|}
\hline Genotype & Reference \\
\hline $\mathrm{E} / \beta$ & {$[46],[47]$} \\
\hline $\mathrm{C} / \beta$ & {$[48]-[50]$} \\
\hline $\mathrm{S} / \mathrm{C}$ & {$[51]-[53]$} \\
\hline $\mathrm{C} / \mathrm{E}$ & {$[54]-[56]$} \\
\hline $\mathrm{E} / \mathrm{S}$ & {$[45],[57],[58]$} \\
\hline
\end{tabular}

\section{REFERENCES}

[1] Torres LS, Okumura JV, Silva DG, Bonini-Domingos CR (2015) Hemoglobin D Punjab: origin, Distribution and laboratory diagnosis. Rev Bras Hematol Hemoter 37:120-126.

[2] Vella F, Lehmann H (1974) Haemoglobin D Punjab (D Los Angeles). J Med Genet 11:341-342.

[3] Belhoul KM, Bakir ML, Abdulrahman M (2013) Misdiagnosis of $\mathrm{Hb}$ D-Punjab/ $\beta$-thalassemia is a potential pitfall in hemoglobinopathy screening programs: a case report. Hemoglobin 37:119-123. https://doi.org/10.3109/03630269.2013.769174.

[4] Das S, Mashon RS (2015) Coinheritance of Hb D-Punjab and $\beta$ thalassemia: diagnosis and implications in prenatal diagnosis. Hemoglobin 39:138-140. https://doi.org/10.3109/03630269.2015.1004335.

[5] Stephens AD, Angastiniotis M, Baysal E et al (2012) ICSH recommendations for the measurement of haemoglobin A2. Int J Lab Hematol 34:1-13.

[6] Shanthala Devi AM, Rameshkumar K, Sitalakshmi S (2016) Hb D: A not so rare hemoglobinopathy. Indian J Hematol Blood Transfus 32:294-298. https://doi.org/10.1007/s12288-013-0319-3.

[7] Heard-Bey F (2001) The tribal society of the UAE and its traditional economy. In: Al Abed I, Hellyer P (eds) United Arab Emirates: A new perspective. Trident Press, London.

[8] Aslan D (2020) Is hemoglobin D trait hematologically silent: comparison with healthy controls and $\beta$-thalassemia carriers. J Pediatr Hematol Oncol 42:e698-e701.

[9] Zakerinia M, Ayatollahi M, Rastegar M, Amanat SH, Askarinejad AR, Amirghofran S, Haghshenas M (2011) Hemoglobin D (Hb D Punjab/Los Angeles and $\mathrm{Hb} \mathrm{D}$ Iran) and co-inheritance with alphaand beta-thalassemia in Southern Iran. Iran Red Crescent Med J 13:493-498.

[10] Mahdavi MR, Jalali H, Kosaryan M, Roshan P, Mahdavi M (2015) $\beta$ Globin gene cluster haplotypes of Hb D-Los Angeles in Mazandaran Province, Iran. Genes Genet Syst 90:55-57.

[11] El-Kalla S, Baysal E (1998) Alpha-thalassemia in the United Arab Emirates. Acta Haematol 100:49-53.

[12] Worthington S, Lehmann $\mathrm{H}$ (1985) The first observation of $\mathrm{Hb} \mathrm{D}$ Punjab beta zero thalassaemia in an English family with 22 cases of unsuspected beta zero thalassaemia minor among its members. J Med Genet 22:377-381.

[13] Giordano PC (2013) Strategies for basic laboratory diagnostics of the hemoglobinopathies in multi-ethnic societies: interpretation of results and pitfalls. Int J Lab Hematol 35:465-479.

[14] Ozsoylu S (1970) Homozygous hemoglobin D Punjab. Acta Haematol 43:353-359.
[15] Silva-Pinto AC, Silva TJ, Moretto EL, Ottoboni MÂ, Rodrigues ES, Covas DT (2014) Blood donor homozygous for Hb D Los Angeles. Transfus Apher Sci 51:219-220.

[16] Desai D, Dhanani H, Shah M, Dayal N, Kapoor A, Yeluri S (2003) Homozygous hemoglobin D diseases: A case report. Internet J Path $3: 1-4$.

[17] Srinivas U, Pati HP, Saxena R (2010) Hemoglobin D-Punjab syndromes in India: a single center experience on cation-exchange high performance liquid chromatography. Hematology 15:178-181.

[18] Thornburg CD, Zimmerman SA, Schultz WH, Ware RE (2001) An infant with homozygous hemoglobin D-Iran. J Pediatr Hematol Oncol 23:67-68.

[19] Dash S (1987) Blood donor homozygous for haemoglobin D. J Assoc Physicians India 35:874.

[20] Sasi S, 20. Ozturk O, Arikan S, Atalay A, Atalay EO (2018) Time estimations by network of beta globin gene cluster haplotypes linked with $\mathrm{Hb}$ D-Los Angeles [ $\beta 121$ (GH4) Glu $\rightarrow$ Gln GAA $\rightarrow$ CAA] mutation in the world populations. Mol Genet Genomic Med 6:11811187.

[21] Hedrick PW (2011) Population genetics of malaria resistance in humans. Heredity 107:283-304.

[22] Taghavi Basmanj M, Karimipoor M, Amirian A et al (2011) Coinheritance of hemoglobin D and $\beta$-thalassemia traits in three Iranian families: clinical relevance. Arch Iran Med 14:61-63.

[23] Panyasai S, Rahad S, Pornprasert S (2017) Coinheritance of hemoglobin D-Punjab and $\beta^{0}$-thalassemia $3.4 \mathrm{~kb}$ deletion in a Thai girl. Asian J Transfus Sci 11:199-202.

[24] Adekile AD, Kazanetz EG, Leonova JY, Marouf R, Khmis A, Huisman TH (1996) Co-inheritance of Hb D-Punjab (codon 121; GAA-->CAA) and beta (0) -thalassemia (IVS-II-1;G-->A). J Pediatr Hematol Oncol 18:151-153.

[25] Theodoridou S, Alemayechou M, Perperidou P Sinopoulou C, Karafoulidou T, Kiriakopoulou G (2009) Compound heterozygosity for $\mathrm{Hb} \mathrm{D}-\mathrm{Punjab} / \beta$-thalassemia and blood donation: Case report. Turk J Hematol 26:100-101.

[26] Fucharoen S, Changtrakun Y, Surapot S, Fucharoen G, Sanchaisuriya $\mathrm{K}$ (2002) Molecular characterization of $\mathrm{Hb}$ D-Punjab [beta121(GH4)Glu--> Gln] in Thailand. Hemoglobin 26:261-269.

[27] Yassin MA, Nair AP, Al Maslamani MS (2020) A case of COVID-19 in a patient with asymptomatic hemoglobin D thalassemia and glucose-6-phosphate dehydrogenase deficiency. Am J Case Rep 21:e925788.

[28] Denic S, Agarwal MM, Al Dabbagh B, El Essa A, Takala M, Showqi S, Yassin J (2013) Hemoglobin A2 lowered by iron deficiency and $\alpha$ thalassemia: should screening recommendation for $\beta$-Thalassemia change? ISRN Hematol 2013:858294.

[29] Paglietti ME, Satta S, Sollaino MC et al (2016) The problem of borderline hemoglobin a2 levels in the screening for $\beta$-thalassemia carriers in Sardinia. Acta Haematol 135:193-199. 
[30] Denic S, Souid AK, Nagelkerke N, Showqi S, Balhaj G (2011) Erythrocyte reference values in Emirati people with and without $\alpha^{+}$ thalassemia. BMC Blood Disord 24:11:1.

[31] Denic S, Aden B, Nagelkerke N, Essa AA (2013) $\beta$-Thalassemia in Abu Dhabi: consanguinity and tribal stratification are major factors explaining the high prevalence of the disease. Hemoglobin 37:351358.

[32] Smith EW, Conley CL (1959) Sickle cell-hemoglobin-D disease. Ann Intern Med 50:94-105.

[33] Cawein MJ, Lappat EJ, Brangle RW, Farley CH (1966) Hemoglobin S-D disease. Ann Intern Med 64:62-70.

[34] Aflatouni MM, Malek M (1978) Sickle cell hemoglobin D disease $1^{\text {st }}$ reported case in Iran. Acta Med Iran 21:153-160.

[35] Ali Al-Barazanchi ZA, Abdulateef SS, Hassan MK, Jaber RZ (2019) Double heterozygosity for hemoglobin S and D Punjab in Basra, Iraq: A clinical and hematological study of 42 patients. J Appl Hematol 10:134-140.

[36] Torres LS, Okumura JV, Belini-Júnior É et al (2016) Phenotypic diversity of sickle cell disease in patients with a double heterozygosity for $\mathrm{Hb} \mathrm{S}$ and $\mathrm{Hb}$ D-Punjab. Hemoglobin 40:356-358

[37] Patel DK, Purohit P, Dehury S, et al. (2014) Fetal hemoglobin and alpha thalassemia modulate the phenotypic expression of $\mathrm{Hb} \mathrm{SD}-$ Punjab. Int J Lab Hematol 36:444-450.

[38] Thalagahage KH, Jayaweera JAAS, Kumbukgolla W, Perera N, Thalagahage E, Kariyawasam J, Dissanayake V (2018) HbS/D-Punjab disease: report of 3 cases from Sri Lanka. Indian J Hematol Blood Transfus 34:350-352.

[39] Hamidieh AA, Jalili M, Khojasteh O, Ghavamzadeh A (2010) First report of successful stem cell transplantation in a patient with sickle cell hemoglobin D disease. J Pediatr Hematol Oncol 32:397-399.

[40] Villanueva H, Kuril S, Krajewski J, Sedrak A (2013) Pulmonary thromboembolism in a child with sickle cell hemoglobin D disease in the setting of acute chest syndrome. Case Rep Pediatr 2013:875683.

[41] Tewari S, Brousse V, Piel FB, Menzel S, Rees DC (2015) Environmental determinants of severity in sickle cell disease. Haematologica 100:1108-1116.

[42] Gupta SK, Dass J, Saxena R (2015) A rare case of double heterozygous state for $\mathrm{HbD}$ and $\mathrm{HbE}$. Indian $\mathrm{J}$ Pathol Microbiol 58:126-127.

[43] Sharma SK, Gogoi S, Dutta R, Mahanta J (2003) Haemoglobin D in a mongoloid non-tribal family: A report from northeast India. Curr Sci 84:752-753.

[44] Edison ES, Shaji RV, Chandy M, Srivastava A (2011) Interaction of hemoglobin $\mathrm{E}$ with other abnormal hemoglobins. Acta Haematol 126:246-248.

[45] Hirani S, Gupta S, Veillon D, Patan S, Master S, Mansour R (2020) The curious case of hemoglobin DC disease masquerading as sickle cell anemia. Hematol Rep 12:8519.

[46] Sripichai O, Makarasara W, Munkongdee T et al (2008) A scoring system for the classification of beta-thalassemia/ $\mathrm{Hb} \mathrm{E}$ disease severity. Am J Hematol 83:482-484.

[47] Chen W, Zhang X, Shang X et al (2010) The molecular basis of betathalassemia intermedia in southern China: genotypic heterogeneity and phenotypic diversity. BMC Med Genet 11:31.

[48] Boreux G, Farquet JJ, Pugin P, Miescher PA, Klein D (1978) Double hétérozygotie hémoglobine $\mathrm{C} /$ bêta-thalassémie chez un algérien présentant une suppression totale de la synthèse de l'hémoglobine A [Haemoglobinosis C/beta-thalassemia double heterozygosity in an Algerian patient with total suppression of haemoglobin A synthesis (author's transl)]. J Genet Hum 26:1-15.

[49] Kumar S, Rana M, Handoo A, Saxena R, Verma IC, Bhargava M, Sood SK (2007) Case report of $\mathrm{HbC/beta(0)-thalassemia} \mathrm{from} \mathrm{India}$ Int J Lab Hematol 29:381-385.

[50] Fattoum S, Guemira F, Abdennebi M, Ben Abdeladhim A (1993) Association $\mathrm{HbC} /$ beta-thalassémie. A propos de onze cas observés en Tunisie $[\mathrm{HbC} /$ beta-thalassemia association. Eleven cases observed in Tunisia]. Ann Pediatr (Paris) 40:45-48.

[51] Nagel RL, Fabry ME, Steinberg MH (2003) The paradox of hemoglobin SC disease. Blood Rev 17:167-178.

[52] Schroeder WA, Powars D, Reynolds RD, Fisher JI (1977) Hb-E in combination with $\mathrm{Hb}-\mathrm{S}$ and $\mathrm{Hb}-\mathrm{C}$ in a black family. Hemoglobin $1: 287-289$

[53] Pecker LH, Schaefer BA, Luchtman-Jones L (2017) Knowledge insufficient: the management of haemoglobin $\mathrm{SC}$ disease. $\mathrm{Br} \mathrm{J}$ Haematol 176:515-526.

[54] Chapman MS, Kiritkumar K, Lund K, Bain BJ (2019) An unusual hemoglobinopathy: compound heterozygosity for hemoglobins $\mathrm{C}$ and E. Am J Hematol 94:144.

[55] Fucharoen S, Fucharoen G, Sanchaisuriya K, Surapot S (2005) Compound heterozygote states for $\mathrm{Hb} \mathrm{C} / \mathrm{Hb}$ Malay and $\mathrm{Hb} \mathrm{C} / \mathrm{Hb} \mathrm{E}$ in pregnancy: a molecular and hematological analysis. Blood Cells Mol Dis 35:196-200.

[56] Schroeder WA, Powars D, Reynolds RD, Fisher JI (1977) Hb-E in combination with $\mathrm{Hb}-\mathrm{S}$ and $\mathrm{Hb}-\mathrm{C}$ in a black family. Hemoglobin 1:287-289.

[57] Masiello D, Heeney MM, Adewoye AH, Eung SH, Luo HY, Steinberg MH, Chui DH (2007) Hemoglobin SE disease: a concise review. Am J Hematol 82:643-649.

[58] Knox-Macaulay HH, Ahmed MM, Gravell D, Al-Kindi S, Ganesh A (2007) Sickle cell-haemoglobin E (HbSE) compound heterozygosity: a clinical and haematological study. Int J Lab Hematol 29:292-301. 